\title{
A VÁROSREHABILITÁCIÓS STRATÉGIÁK SZEREPE AZ ÉPÜLET- ÉS LAKÁSÁLLOMÁNY MEGÚJULÁSÁBAN
}

\author{
(Urban Regeneration Strategies in the Renewal of the Building- \\ and Dwelling Stocks in Hungary)
}

\author{
EGEDY TAMÁS
}

Kulcsszavak:

városrehabilitáció városrehabilitációs stratégia lakásprogram

A rendszerváltozás után közel egy évtized telt el, mig az állami és a helyi önkormányzati döntéshozók felismerték az évtizedekig elhanyagolt, lepusztulobban lévö épület-és lakásállomány megmentésének jelentöségét, illetve a felújitúsi folyamatot képesek legyenek megfelelö stratégiákkal irányítani és finanszirozni. Az elmúlt tiz évben országos és helyi szinten megszülettek az elsö, sikeres városrehabiliticiós stratégiák. Tanulmányunkban ezeket a városfelájítási törekvéseket tekintjük át, keresve az országos, fövárosi és vidéki nagyvárosi rehabilitációs stratégiáknak a hazai épület-és lakásállomány megújulásában játszott szerepét.

\section{Bevezetés}

Az elmúlt évtized gazdasági változásai és a globalizáció sok városban a gazdasági, társadalmi és fizikai (épített) környezet problémáinak a növekedéséhez vezettek. A városregenerációban részt vevő szervezetek felismerték, hogy a fenti problémák sokrétüsége miatt a városfelújítás csak egy stratégiailag megalapozott, lokális cselekvésre alapozott, multiszektorális és a kölcsönös partnerség keretei között zajló tevékenységként mủködhet sikeresen (Parkinson 1996). A városrehabilitációban az izolált városátalakítási projektek helyett egyre inkább elötérbe került a gazdasági, társadalmi és kömyezeti regeneráció feltételeinek a megteremtése. Felismerték, hogy a területi tervezés nem kizárólag csak fizikai értelemben vett tervezés és területhasznosítási tevékenység, hanem társadalmi, gazdasági, kömyezeti és politikai folyamatok összessége, amelynek müködtetéséhez stratégiai gondolkodás szükséges. Fontos tényezô, hogy nem elég kizárólag stratégiai irányokat meghatározni, hanem a különbözó szintú stratégiai célkitüzéseket egy átfogóbb és összetett területi tervezési folyamatba kell integrálni. A stratégiai tervezés egyúttal lehetővé teszi azt, hogy a környezeti és társadalmi tényezők figyelembe vételével a városrészek hosszú távú gazdasági fejlödését ne veszélyeztessük (Roberts-Sykes 2000). A stratégiai megközelítésben a döntéshozatal regionális és lokális szintre tơrténö decentralizációjával pedig egyre több helyi szervezetnek nyílik lehetősége, hogy a városrehabilitáció folyamatába bekapcsolódjon.

A városrehabilitációban (városregenerációban) felismerhetỏ nemzetközi trendek ellenére az országos és helyi szintű stratégiák skálája Európában rendkívül széles. 
Egedy Tamás : A városrehabilitációs stratégiák szerepe az épület-és lakásállomány megújulásában. Tér és Társadalom 20. évf. 37-56. $p$.

Természetesen ez szorosan összefügg azzal, hogy az adott országok társadalmi és gazdasági helyzete nagyban különbözhet egymástól csakúgy, mint a felújításra váró városrészek és lakónegyedek. A nemzetközi tapasztalatok azt mutatják, hogy nincsenek egységesen követendő univerzális stratégiák és modellek a városrehabilitációban, hanem a helyi stratégiák kidolgozása és a célkitüzések megfogalmazása során mindig figyelembe kell venni a helyi (országos, regionális, lokális) viszonyokat és sajátosságokat.

Tanulmányunkban áttekintjük azokat a legfontosabb állami, önkormányzati, fővárosi és vidéki nagyvárosi stratégiákat, amelyek sikeresen járulhatnak hozzá a hazai épületés lakásállomány megújításához. Ennek tükrében keressük a városrehabilitáció és az épületek-lakások felújításának kapcsolódási pontjait a stratégiákban, illetve budapesti és vidéki nagyvárosi példákon keresztül mutatjuk be a lakókörnyezet és a társadalom rehabilitációjának néhány lehetséges formáját. A helyi szintủ stratégiák bemutatása során a lakónegyedek fejlesztési lehetőségeit vesszük számba, a barnamezős területek rehabilitációs lehetőségeit ezúttal nem vizsgáljuk. A stratégiai tervek, városrehabilitációs programok és célkitüzések áttekintésével lehetővé válik, hogy a Magyarországon folyó városfelújitási tevékenységet jobban átlássuk és átfogóbb képet kaphassunk a városfelújítás aktuális fejlődési irányairól és lehetőségeiről.

\section{Állami szintü városrehabilitációs stratégiák}

\section{A városrehabilitáció szerepe az Európai Uniós tervezési stratégiánkban}

Mivel az Európai Unió a lakásállomány fejlesztésével (lakásépítés, lakások felújítása stb.) kapcsolatos programokat nem finanszíroz, ezért ebben a fejezetben a Nemzeti Fejlesztési Tervek rövid bemutatásával csak a városrehabilitációval összefüggő kérdéseket tárgyalhatjuk. A fenti okok miatt a Fejlesztési Tervek közvetlenül csak az épületállomány felújításában játszanak szerepet, de természetesen a lakókörnyezet megújulásán keresztül lakáspiaci hatásaik kimutathatók, így a lakáshelyzet javulásában játszott szerepük közvetve bár, de mégiscsak jelentkezik.

\section{Az I. és II. Nemzeti Fejlesztési Terv}

Az I. Nemzeti Fejlesztési Terv (NFT) célja lényegében az volt, hogy a 2004-2006 közötti időszakra kijelölje azokat a fejlesztéspolitikai célkitüzéseket és prioritásokat, amelyek elérésében Magyarország a Strukturális Alapok támogatását felhasználja. Az NFT hosszú távú célkitüzése a lakosság életminöségének javítása volt. Ezen belül a Terv három fő specifikus célt jelölt meg, a városrehabilitáció tekintetében ezek közül a „Jobb minöségü környezet és kiegyensúlyozottabb regionális fejlödés" specifikus cél emelendő ki. Az I. NFT a városrehabilitációval kapcsolatos célkitüzéseket és finanszírozási lehetőségeket a „Regionális és helyi potenciál erösítése” prioritáson belül a „Regionális Fejlesztési Operatív Programban” jelöli ki.

Ez az operatív program alapvetően a regionális fejlesztési potenciál kihasználására, a nehézségekkel küzdö városi területek problémáinak kezelésére, valamint a hátrányos helyzetü társadalmi csoportok támogatására helyezte a hangsúlyt. Ennek 
Egedy Tamás : A városrehabilitációs stratégiák szerepe az épület-és lakásállomány megújulásában. Tér és Társadalom 20. évf. 37-56. $p$.

megfelelően a program egyik prioritása a „Térségi infrastruktúra és a települési környezet fejlesztése" volt. Az infrastrukturális beruházások között az úthálózat korszerüsítése, a tömegközlekedés fejlesztése, kerékpárutak építése, valamint a közösségi létesítmények helyzetének javítása járultak hozzá a városrehabilitáció elörehaladásához. A települési környezet megújulásában említést érdemelnek a lakótelepek, közterületek és barnamezös területek rehabilitációjára, valamint az épített örökség megörzésére benyújtott sikeres pályázatok.

Hangsúlyozni szeretnénk, hogy az első NFT-ben a specifikus célok és a prioritások között is szerepel a humán erőforrások fejlesztése, illetve külön operatív program gyüjti egybe a hátrányos helyzetben lévö csoportok foglalkoztatásával, képzésével és továbbképzésével kapcsolatos intézkedéseket. A fizikai környezet megújítása mellett a társadalmi környezet fejlesztésére is hangsúlyt fektetett a terv, kormányzati szinten is felfedezhetjük tehát az átfogó szociális rehabilitációra való törekvés első nyomait.

A fejlesztési terv keretében megvalósuló rehabilitációs fejlesztésekröl - mivel a program még jelenleg is fut - egyelöre nehéz átfogó képet alkotni, ugyanakkor a benyújtott pályázatok és a finanszírozás sarokszámai ismertek (1. táblázat).

\section{TÁBLÁZAT}

A Regionális Fejlesztési Operatív Program (ROP) finanszírozási terve (2004-2006) (Mrd Ft)

(Financial Calculation of the Regional Development Operative Program, 2004-2006)

\begin{tabular}{|c|c|c|c|c|}
\hline & $\begin{array}{c}E U- \\
\text { támogatás }\end{array}$ & $\begin{array}{l}\text { Nemzeti } \\
\text { forrás }\end{array}$ & Magánforrás & Összesen \\
\hline $\begin{array}{l}\text { Turisztikai potenciál } \\
\text { fejlesztése }\end{array}$ & 20,7 & 7,7 & 18,7 & 47,1 \\
\hline $\begin{array}{l}\text { Térségi infrastruktúra } \\
\text { és települési környezet } \\
\text { fejlesztése }\end{array}$ & 51,8 & 16,4 & 0,0 & 68,2 \\
\hline $\begin{array}{l}\text { Település- } \\
\text { rehabilitációs akciók }\end{array}$ & 17,7 & 5,9 & 0,0 & 23,6 \\
\hline $\begin{array}{l}\text { Humán erőforrás } \\
\text { fejlesztés }\end{array}$ & 13,7 & 3,8 & 0,7 & 18,2 \\
\hline $\begin{array}{l}\text { Technikai segítség- } \\
\text { nyújtás }\end{array}$ & 5,5 & 1,8 & 0,0 & 7,3 \\
\hline Összesen & 91,7 & 29,7 & 19,4 & 140,8 \\
\hline
\end{tabular}

Forrás: Nemzeti Fejlesztési Terv és EU Támogatások Hivatala.

A Regionális Fejlesztési Operatív Programról 2006. január 16-án kiadott összefoglaló szerint a 2004-2006 időszakban - a tervezettöl eltéröen - összesen 107 Mrd Ft állt a ROP rendelkezésére, aminek 94\%-a lekötésre került, s az év elején a teljes összeg 79\%-áról már aláírták a szerzödést. Összesen 2206 pályázat érkezett be a programra, s ebböl 331 pályázat rendelkezik szerződéssel összesen 75 Mrd Ft értékben. A pályázatok közül 30 projekt szerződött városrehabilitációs fejlesztésre, amelyekből eddig egy teljesen, egy pedig részben megvalósult. 
Egedy Tamás : A városrehabilitációs stratégiák szerepe az épület-és lakásállomány megújulásában. Tér és Társadalom 20. évf. 37-56. $p$.

A II. Nemzeti Fejlesztési Terv (Magyarország Nemzeti Stratégiai Referenciakerete címen) a 2007-2013 közötti fejlesztési célokat, prioritásokat és intézkedéseket tartalmazza. Mivel a Terv még kidolgozás alatt áll és végleges elfogadása 2006 második félévében várható, csak előzetes információkkal rendelkezünk a terv városrehabilitációt érintő fejlesztési lehetôségeiről. A fö fejlesztési tengelyek előreláthatólag a gazdaság versenyképességének javítása, az emberi erőforrások fejlesztése, a kömyezet fejlesztése, a területi (regionális) fejlesztések és a kormányzás hatékonyságának növelése lesznek. A tervben a társadalmi környezet helyzetének javítása az első NFT-hez hasonlóan kiemelt hangsúlyt kap, a környezeti fejlesztések jelentősége is felértékelödik, ugyanakkor a városrehabilitációnak a tervezett struktúrában sajnos csak alárendelt szerepe lesz, s a települési környezet fejlesztésével kapcsolatos prioritásokat a régiók operatív programjainak a hatáskörébe utalja. Előzetes tájékozódásunk alapján előreláthatólag a Közép-Magyarországi Régió fogja kiemelt prioritásként kezelni a minőségi élethez szükséges települési tényezők fejlesztését, a természeti és az épített környezet rehabilitációját.

\section{Állami beavatkozások és kormányzati intézkedések a lakásállomány fejlesztésére}

A rendszerváltozás után drasztikus mértékben visszaesett a lakásépítés. Az új lakások építése az 1975. évi csúcstól fokozatosan csőkkent az 1994. évi első mélypontig, majd 1999-ben újabb mélypontot ért el (ebben az évben az újonnan épuilt lakások száma 20 ezer alá csökkent). A lakásépítések számának ilyen jelentős visszaesésében az állami szektor kivonulása játszotta a döntỏ szerepet, hiszen gyakorlatilag megszủnt az állami és önkormányzati lakásépités. Az épitésben a fö szerepet a lakosság vette át, ugyanakkor a kilencvenes évek derekán a vállalkozói lakásépítés - ami jelentösen hozzájárulhatott volna a számok javulásához - még nem futott fel eléggé.

Az 1990-es években tapasztalható negativ tendenciák megváltoztatására központi intézkedéseket hozott a kormányzat: 1994-ben elsősorban szociálpolitikai támogatásokkal támogatta a lakásépítést, míg 2000-ben a lakáshoz jutás hitelezési feltételeit javította. A kormányzati közbelépéseknek köszönhetỏen mindkét mélypont után fellendưlés volt tapasztalható a lakáspiacon. Az állam és az önkormányzatok döntéseikkel, a jogszabályok alakításával és támogatások nyújtásával tehát jelentősen befolyásolhatják a lakáspiaci folyamatokat. Az összes intézkedés és ezek hatásainak áttekintése természetesen meghaladná jelen dolgozat kereteit, ezért csak a Széchenyi-terv, a Nemzeti Lakásprogram és a Panelprogram jelentőségére térnék ki rōviden.

\section{A Széchenyi-terv}

A 2000-ben elfogadott, hat évre kitekintö, középtávú terv a 2001-töl 2006-ig terjedő időszak kiemelt fejlesztéseit tartalmazta. A fejlesztési terv fö programterületei a vállalkozáserősítési, a turizmusfejlesztési, a regionális gazdaságfejlesztési, a kutatásfejlesztési és innovációs, az információs társadalom- és gazdaságfejlesztési program, végül a lakásprogram voltak. 
Egedy Tamás : A városrehabilitációs stratégiák szerepe az épület-és lakásállomány megújulásában. Tér és Társadalom 20. évf. 37-56. $p$.

TÉT XX. évf. 2006 - 1

A városrehabilitációs stratégiák ...

41

A Széchenyi-terv Lakásprogramja négy alprogramba foglalta össze azokat az intézkedéseket és támogatási lehetőségeket, melyeket a lakáshelyzet javitása érdekében szükségesnek látott (2. táblázat).

\section{TÁBLÁZAT}

A Széchenyi-terv Lakásprogramjának alprogramjai és célkitüzései

(Programs and Priorities of the Housing Program of Széchenyi Development Plan)

1. A lakásállomány bövítése

Új, korszerū lakások építésének ösztönzése

Vállalkozásszerủ lakásépítés ösztönzése

2. A lakásállomány korszerüsítése

Az energiatakarékossági beruházások ösztönzése

A tömbház-rehabilitáció ösztönzése

A lakásállomány felújittásának, korszerúsítésének ösztönzése

3. A lakáshitelezés, a lakáshoz jutás elösegitése és a mobilitás növelése

A hitelezés részarányának növelése a lakásberuházásokban

A hosszú lejáratú hitelek részarányának ösztönzése

Helyi és munkahelyi támogatások ösztönzése

4. A bérlakásszektor részarányának növelése, a réteg-ês szociális problémák kezelése

Bérlakások építésének ösztönzése

A szociálisan rászorultak részére speciális programok müködtetése

Forrás: Széchenyi-terv - Lakásprogram.

A városrehabilitáció szempontjából a Terv második, A lakásállomány korszerüsitése alprogramja érdemel említést, hiszen ebben fogalmazódik meg egyrészt a panellakások energiatakarékos felújításának és átalakításának, valamint a tömbház-rehabilitációs program elindításának szükségessége. Míg elöbbi a panelházak fütési rendszerének korszerüsítésén keresztül a családok költségeinek csökkentését, illetve az iparosított (házgyári) technológiával épült másodlagos szerkezeteinek, belső hálózatainak felújítását célozta, utóbbi a nagyobb városok belvárosainak és régebbi vărosnegyedeinek korszerüsítését tüzte ki célul.

A Terv a lakásállomány bövitését különbözö vissza nem térítendő támogatások, pénzügyi közvetítőkön keresztül nyújtott támogatások nyújtásával finanszírozta, $a$ lakáshitelezés, a lakáshoz jutás elösegitését és a mobilitás növelését pedig kamattámogatással, állami garancia vállalásával, s különbözỏ adó- és illetékkedvezményekkel biztosította. A Lakásprogram negyedik - A bérlakásszektor részarányának növelése, a réteg- és szociális problémák kezelése - alprogramján keresztül az állami támogatású bérlakásprogram a kormányzat otthonteremtési programjának fontos, új elemeként jelent meg. A program szerint vissza nem térítendỏ központi támogatásra pályázhattak azok a települések, amelyek szociális vagy költségelvú bérlakásokat alakítanak ki, vagy építenek. Az alprogram emellett támogatta a köztisztviselöi réteg lakáshoz jutását, nyugdijasházak és fecskeházak építését, valamint a szociálisan 
Egedy Tamás : A városrehabilitációs stratégiák szerepe az épület-és lakásállomány megújulásában.

Tér és Társadalom 20. évf. 37-56. $p$.

42 Egedy Tamás

TÉT XX. évf. 2006 — 1

hátrányos helyzetủek közül kiemelten a cigány lakosság és a fogyatékkal élő emberek lakáshelyzetének javítását.

A Terv a 2001-2002-es időszakban a rendelkezésre álló adatok szerint a Lakásprogram finanszírozására 69,9 Mrd Ft-ot, illetve 72,6 Mrd Ft-ot ütemezett, végül közel 30 milliárd forint támogatást osztottak szét és a feltételezések szerint ez öszszesen mintegy 40 milliárd forintnyi lakásberuházást segített elő. A lakásprogramban föleg önkormányzatok vettek részt, $s$ alapvetően bérlakások építésére kaptak támogatást, ami mintegy 8 ezer $60 \mathrm{~m}^{2}$-es bérlakás építését tette lehetövé.

\section{A Nemzeti Lakásprogram (Otthon Európában program)}

A kormányzat a lakáshelyzet javítására Otthon Európában címmel Nemzeti Lakásprogramot dolgozott ki, és 2003 januárjában vitára bocsátotta azt. A vitaanyag a legfontosabb stratégiai célok között a következőket említi: a) a lakosság igényeit kielégítő, európai színvonalú, megfizethető lakáskínálat kialakítása; b) az épített és természeti környezet értékeinek megörzése, minőségének és lakhatóságának javítása, az életminöség javulása; c) a rászorultak számára a piac müködésével összhangban lévő, igazságos, arányos és fenntartható támogatási rendszer létrehozása és müködtetése.

Ahhoz, hogy a nyugat-európai lakásviszonyokat megközelíthessük, a lakásállomány 5-10\%-os bővítésére lenne szükség, valamint meg kell oldani az állomány 30\%-ának teljes felújítását vagy cseréjét, illetve további 25-30\%-ånak javítását, korszerüsítését. A 15 éves program sikeres végrehajtása érdekében a program szerint összesen évente 38-40 ezer új lakás felépítése és 80-100 ezer lakás felújítása szükséges.

A stratégiai célok megvalósításához szükséges lépéseket a Nemzeti Lakásprogram öt meghatározó feladatcsoportba sorolja, melyeket a lakáspolitika pilléreinek nevez: 1. pillér: Ingatlan- és építési szabályozás; 2. pillér: Építés- és befektetés-ösztönzés; 3. pillér: A lakáshoz jutási és szociális támogatások rendszerének reformja; 4. pillér: Kultúra, képzés, kommunikáció; 5. pillér: Zászlóshajó projektek.

A városrehabilitáció szempontjából a 2. pillér érdemel említést. Ebben a pillérben célprogramként szerepel a panelprogram és a lakótelepek humanizálása is. Ez a 15 éves átfutású program mintegy 300 ezer lakótelepi lakást érintene, figyelembe véve a helyi viszonyokat is. A lakótelepek fizikai, szociális, gazdasági állapotát szem elößt tartva komplex-felértékelö, komplex-stabilizáló, energia-korszerüsítési és épület-felújítási programokat alkalmazna a program, támaszkodva a helyi közösségi beruházásokra.

További fontos célprogram a belsö városrészek és településközpontok megújitása. A városrehabilitáció a lakásstratégia egyik kiemelt eleme lesz: a rehabilitáció mintegy 200 ezer lakást érintene, s természetesen tovább folyna a társasházak felújítása is. A tervek szerint a felújítási költségek $20-30 \%$-át lehet majd pályázati úton elnyerni. Külön program foglalkozik a bérlakásépités ösztönzési rendszerének kialakitásával: A program a 2007-2018 közötti időszakra az EU bérlakás-rendszerének színvonalához való felzárkózást tủzi ki célul. Azt kívánja elérni, hogy a bérlakások aránya a teljes lakásállományon belül érje el a 15\%-ot, a magántulajdonú bérlakások száma megközelítse a 300 ezret, az önkormányzati, illetve lakástársasági bérlakások száma pedig elérje a 150-150 ezres nagyságrendet (3. táblázat). Egyik fontos 
Egedy Tamás : A városrehabilitációs stratégiák szerepe az épület-és lakásállomány megújulásában. Tér és Társadalom 20. évf. 37-56. $p$.

elöremutató eleme a programnak, hogy egy pályázati rendszer keretében támogatni kívánja a bérlakás-vállalkozások PPP szerzödéseit, azaz a vegyes - szociális és piaci alapú - üzemeltetést részesíti előnyben.

\section{TÁBLÁZAT}

A Nemzeti Lakásprog ram stratégiai célkitüzéseinek néhány mutatója (Strategic Data of the National Housing Program)

\begin{tabular}{lcrr}
\hline & 2003 & 2006 & 2018 \\
\hline Évente épített új lakások aránya (\%) & 3,5 & 3,9 & 5,0 \\
Bérlakások aránya (\%) & 9,0 & 10,0 & 15,0 \\
Lakásmobilitás (\%) & 3,5 & 4,0 & 8,0 \\
Lakásár/jövedelem hányados (év) & 5,0 & 4,8 & 3,5 \\
Zsúfolt lakások aránya (\%) & 13,5 & 10,0 & 5,0 \\
Lakáskiadások aránya GDP-ben (\%) & 1,6 & 1,8 & 2,2 \\
\hline
\end{tabular}

Forrás: Nemzeti Lakásprogram.

\section{A panelprogram}

Magyarországon a 4 millió 65 ezer lakásból 837 ezer található lakótelepeken, ebböl 772 ezer lakott, s a lakótelepi lakásokban jelenleg közel 1,9 millió ember él. Budapest 121 lakótelepén 260 ezer lakásban (a lakott lakások 34,8\%-a) mintegy 622 ezer ember él. A megyei jogú városokban még a budapestinél is magasabb arányokat találunk, mivel a lakások 43,3\%-a van lakótelepi környezetben (pl. Miskolcon és Tatabányán arányuk meghaladja a 60\%-ot). A lakótelepi lakásoknak ugyanakkor csak körülbelül 62\%-a, összesen 517 ezer lakás épült házgyári paneles technológiával. Panelépületekkel leggyakrabban a fövárosban és a 100 ezer fönél népesebb nagyvárosokban találkozhatunk.

A lassan egy évtizede folyó panelprogram az épület- és lakásállomány megújitásában kiemelt szerepet játszik. A panelépületek felújítására eddig kétszer lehetett állami forrást nyerni: 1997-től a német panelhitelből és 2001-töl a Széchenyitervböl. Az elöre gyártott technológia felhasználásával épült lakóépületek felújitásának támogatására a lakáscélú állami támogatásokról szóló 12/2001. (I. 31.) Kormányrendelet 2001. február 1-jétől teremt lehetőséget. Ennek keretében az épületek utólagos höszigeteléséhez és gépészeti rendszereinek energiatakarékos felújításához, korszerűsítéséhez lehet vissza nem térítendő állami támogatásra pályázatot benyújtani. A 2001-ben indult panelprogram első négy évében együttvéve 4,6 Mrd-os állami támogatás jutott a lakások korszerüsítésére, amiböl összesen 37 ezer lakás újult meg. Az eddig elnyert pályázati összegek alapján összeállított listát Székesfehérvár vezeti, amely 6024 lakás felújítására összesen több mint egymilliárd forint állami támogatást nyert el, míg Pécs 640 millió forint támogatást kapott, amiböl 7220 lakás korszerüsítését oldhatták meg.

A 2005-ben ismételten meghirdetett panelrekonstrukcióra, amely az ismert ,panelprogram" és a kémények biztonságtechnikai felújítását támogató pályázat mellett lakbér-támogatási és a lakásonkénti fütésszabályozás megvalósítását támogató 
Egedy Tamás : A városrehabilitációs stratégiák szerepe az épület-és lakásállomány megújulásában.

Tér és Társadalom 20. évf. 37-56. $p$.

$44 \quad$ Egedy Tamás

TÉT XX. évf. 2006 - 1

pályázati kírást is tartalmazott, összesen másfélezer pályázat érkezett. 14,2 milliárd forintot ütemezett be az állam a programra, ami kiegészülve az önkormányzatok és a lakók saját hozzájárulásával összesen 75 ezer lakás felújitását teszi lehetővé. A támogatás célja az iparosított technológiával készült, ma már nem korszerủ lakóépületek felújítása, illetve ezen épületek gépészeti rendszereinek, berendezéseinek, valamint közvetlen környezetében lévő területek (utak, parkolók, játszóterek, parkok) korszerüsítése, felújítása.

A 2005 első tizenegy hónapjában 602 db pályázat érkezett, mintegy 5,5 milliárd forint támogatási igénnyel, amely 29684 lakást érint. A legtöbb pályázat Székesfehérvárról (96), Szegedről (74), és Kaposvárról (53) érkezett. A legnagyobb támogatási összegért folyamodó városok Székesfehérvár (1,3 milliárd $\mathrm{Ft})$, Szeged (680 millió Ft) és Nyíregyháza (467 millió Ft), a fővárosból pedig Kőbánya Önkormányzata (363 millió Ft) voltak. 2005-ben először a lakókörnyezet megújítására is lehetett támogatást kérni (utak, járdák, parkolók rendbe hozatala), e lehetöséggel eddig Eger, Budaörs, Miskolc és Szeged élt.

A jelenlegi szabályozás szerint a felújítás lakásonkénti 1,2 millió forintra kalkulált költségéhez az állam és az önkormányzat egyharmad-egyharmad részben járul hozzá, a fennmaradó 400 ezer forintot a tulajdonosnak kell állnia. Mivel ez sok magánszemélynek és önkormányzatnak megoldhatatlan terhet jelent, ezen önrészekre Panel Plusz néven 15 éves futamidejü, állami támogatással igénybe vehetö, 5-6\%-os kamatozású hitelt vezetett be a kormány?.

\section{Egyéb állami és önkormányzati hitelprogramok, pályázati lehetöségek}

Az épület- és lakásállomány megújításának áttekintésekor természetesen nem feledkezhetünk meg a különbözö állami és önkormányzati hitelprogramokról és pályázati lehetőségekről (pl. lakáshitel-programok, társasházak felújításának támogatása stb.). Mivel gyakorlatilag minden fövárosi kerület és nagyobb város önkormányzata pályázati úton támogatja a helyi épület- és lakásállomány megújulását, illetve számos hitelkonstrukciós forma létezik, ezek részletesebb áttekintése meghaladná ezen tanulmány kereteit. Ezért csak az állami lakáshitel-programokat és az önkormányzatoktól igényelhető támogatások alapelveit érintjük röviden.

A lakásépítés költségei és a lakásárak az 1990-es évek második felében drasztikusan megemelkedtek és nem voltak szinkronban a fizetöképes kereslettel, ennek következtében jelentősen visszaesett a lakásépítések száma hazánkban. A helyzetet tovább rontotta, hogy a felvehetö hitelek kamatai nem ritkán a 25-30\%-ot is elérték. 2000-ben a kormány a helyzet javítására állami támogatási hitelprogramot dolgozott ki, s vissza nem térítendö állami támogatással és a banki lakáshitelek kamattámogatásával segíti a lakáshoz jutást, illetve felújítást ${ }^{2}$. Jelenleg ennek az állami támogatási konstrukciónak a keretében 12-féle lakáscélú támogatási típust lehet igénybe venni. A lakástámogatási rendszer első két évében 2001-2002-ben 230 ezer lakáshitelt folyósítottak a bankok 643 milliárd forint összegben, ebböl támogatott hitel 101 ezer volt, 449 milliárd forint összegben. 2003 és 2004 között 
Egedy Tamás : A városrehabilitációs stratégiák szerepe az épület-és lakásállomány megújulásában. Tér és Társadalom 20. évf. 37-56. $p$.

TÉT XX. évf. 2006 - 1

A városrehabilitációs stratégiák ...

45

320 ezer lakáshitelt folyósítottak a bankok 1344 Mrd Ft összegben, amiből az államilag támogatott hitel 197 ezer volt, $1028 \mathrm{Mrd} \mathrm{Ft} \mathrm{összegben.}$

Az épületállomány megújításában nem kis szerepe van a helyi önkormányzatok által kiírt, saját erőforrásaikból fedezett társasházi felújítási pályázatoknak is. A fövárosi kerületekben és a vidéki nagyvárosokban - természetesen az önkormányzatok anyagi lehetőségeinek függvényében - évente általában 100-200 millió Ft körüli összeget fordítanak a társasházak felújítására. A pályázathoz a társasházaknak általában 50\% sajáteröt kell felmutatni, illetve Budapesten a fövárosi önkormányzathoz benyújtott pályázatoknál létezik az egyharmados sajáterő is a kerületi önkormányzatok szintén egyharmados támogatásával. A beérkezett pályázatok száma alapján elmondható, hogy nagy igény mutatkozik a társasházak felújítására. A probléma elsősorban ott jelentkezik, hogy vagy az önkormányzat nem tud kellö anyagi támogatást nyújtani a beérkezett pályázatokra, azaz a pályázati összegek lényegesen meghaladják a kiírt támogatás mértékét, vagy a lakóközösségek nem tudnak pályázni, mert nem képesek elöteremti a szükséges önrészt.

\section{Fövárosi rehabilitációs stratégiák}

A régi, leromlott állapotú épületállomány nagy arányú bontása és új lakások épitése

Középső-Ferencváros

A középsö-ferencvárosi rehabilitációs területre az 1970-es években még házgyári épületeket terveztek, az 1980-as évek elején azonban alapvetỏen megváltozott a koncepció és elötérbe került a hagyományos városi utcahálózat és tömbrendszer megtartása kis terek kialakításával, a belső udvarok parkosításával. A nyolcvanas évek derekán tömbrehabilitációnak induló folyamat a rendszerváltozás után is tovább folytatódott, de a beruházást korábban finanszírozó önkormányzat helyét folyamatosan a magántöke vette át. Az 1990-es években elötérbe került a régi, rossz állapotú épületek és lakások lebontása és helyưkön új lakások felépítése. Az új lakások építése már az 1980-as évek végén elkezdődött, s változó intenzitással mindmáig tart. A legdinamikusabb időszak a lakásépítésben - köszönhetően a magántőkének - 2001-2004 között volt: összesen 1906 új lakás épült fel (a kezdetektöl épült összes új lakás közel 62\%-a). A program teljes időszakában 2004 év végéig 1014 bontott lakás helyén 3089 új lakás épült. Az új építéshez képest az (önkormányzati) épületek és lakások felújítása jelentösen lemaradt: 2003 végéig 32 épületben mintegy 600 lakást újítottak fel. A rehabilitáció 1983-2003 közötti idöszakában jelenértéken számolva közel 29 Mrd Ft közpénzt használtak fel a fejlesztésekre (Locsmándi 2005). A folyamat mára eljutott oda, hogy egységnyi önkormányzati beruházás háromszor annyi magántőkét mozgósít. 
Egedy Tamás : A városrehabilitációs stratégiák szerepe az épület-és lakásállomány megújulásában.

Tér és Társadalom 20. évf. 37-56. $p$.

46 Egedy Tamás

TÉT XX. évf. 2006

4. TÁBLÁZAT

Az új lakásépítés legfontosabb adatai a Középsö-Ferencvárosban

(Data on New Dwellings Built in Middle-Ferencváros)

\begin{tabular}{cccc}
\hline Évek & Épült (db) & $\begin{array}{c}\text { 1989-2004 } \\
\text { \%-ában }\end{array}$ & Éves átlag (lakás/év) \\
\hline $1989-1991$ & 436 & 14,1 & 145,3 \\
$1992-1996$ & 218 & 7,1 & 43,6 \\
$1997-2000$ & 529 & 17,1 & 132,3 \\
$2001-2004$ & 1906 & 61,7 & 476,5 \\
Összesen & 3089 & 100,0 & 193,1 \\
\hline
\end{tabular}

Forrás: Locsmándi 2005.

Az elmúlt 20 évben az épület- és lakásállomány jelentős része tehát kicserélödött, ami együtt járt a helyi társadalom gyökeres átalakulásával. A megújuló városrészben a dzsentrifikációs folyamatnak köszönhetöen az alacsonyabb státuszú rétegek helyét tehetösebb, jobb anyagi lehetőségekkel rendelkezö, fiatalabb rétegek vették át. A középsö-ferencvárosi rehabilitációra napjainkban úgy tekintenek, mint a legsikeresebb hazai városfelújítási projektre.

\section{Középső-Józsefváros - Corvin Sétány Projekt}

Az 1999-2002. között kidolgozott Corvin Sétány (korábban Corvin-Szigony) Projekt PPP-beruházásként épül meg, s jelentő arányú bontással számol. Ehhez a területen élóket ki kellett költöztetni, így a program gyakorlatilag az eredeti lakónépesség teljes kicserélödésével jár. A rehabilitációs terület lakosságának $80 \%$-a bérlakásban lakott, 20\% saját lakásban, ami megkönnyítette a bontásra ítélt lakások kiürítését. A magántulajdonosok lakásainak megvásárlása és a bérlök elköltöztetése után 2005 végére 230 család otthonát már le is bontották. A lebontandó lakások száma megközelíti majd az 1500-at, ugyanakkor közel 1000 lakás megmarad. A lakónegyedben a lakásfunkció megtartása keretében összesen 50 épület újul meg, s 2500-3 000 lakás épül fel. Emellett kiskereskedelmi, szolgáltató és vendéglátó egységek, valamint irodák is helyet kapnak majd a területen. A 10 éves futamidejü projekt a fiatal, városi kultúra és életmód iránt érdeklődő rétegeket célozza meg. A Sétány feladata az lesz, hogy ellássa egy új kulturális városközpont és közösségi tér funkcióját, továbbá zöldterületeivel megvalósuljon egy összetett, minőségi, urbánus lakókörnyezet. A Projekt összterülete $208000 \mathrm{~m}^{2}$, melyböl $90000 \mathrm{~m}^{2}$ a befektetési terület. Az ingatlanfejlesztési tervek szerint $255000 \mathrm{~m}^{2}$ lakó, és $60000 \mathrm{~m}^{2}$ kereskedelmi-intézményi új építményfelület jön létre, a közterület-fejlesztés pedig eléri a $20000 \mathrm{~m}^{2}$-t. A projekt költségei 2009-ig elöreláthatólag 2-3 Mrd Ft körül alakulnak. 
Egedy Tamás : A városrehabilitációs stratégiák szerepe az épület-és lakásállomány megújulásában. Tér és Társadalom 20. évf. 37-56. $p$.

TÉT XX. évf. 2006 - 1 A városrehabilitációs stratégiák ...

\section{Felújitás és lakásépités az eredeti épitészeti struktúra és épületállomány megtartásával}

\section{Józsefváros}

A 2004-ben a józsefvárosi rehabilitációt irányító Rév8 Rt. elkészítette Józsefváros 15 éves kerületfejlesztési stratégiáját, amely a kerületet 11 önálló ,negyedre” osztotta fel. A fejlesztési stratégia egy szerves fejlődés eredménye, amely az 1996 és 2003 között született városfejlesztési koncepciók legfontosabb elemeit tartalmazza. A dokumentum Józsefváros területét 11 önálló arculattal rendelkező területi egységre, ún. negyedre osztja, amelyek kialakításában ezen városrészek eltérő arculata és identitása játszotta a legfontosabb szerepet. A negyedekhez tartozó integrált programok az egyes területi egységek sajátosságai, egyedi helyzete és az ott jellemző problémáik alapján határozzák meg a szükséges fejlesztéseket. A stratégia két átfogó programot tartalmaz: egy lakásprogramot és egy társadalomfejlesztési programot, melyek társadalmi, gazdasági és környezeti célokat fogalmaznak meg. A lakásprogram célja az önkormányzati lakásportfolió átalakítása a finanszírozhatóság érdekében, melynek legfontosabb eszközei a leromlott állapotú, nem felújítható, gazdaságtalan és építészeti értéket nem képviselö épületek és lakásállomány lebontása ${ }^{3}$, illetve az építészetileg értékes lakóépuiletek, valamint a lakókörnyezet felújítása a magántőke és a nonprofit szektor bevonásával. A társadalomfejlesztési program elsősorban a kerületi kötődés, a városrészek vonzerejének növelését, az oktatás és a kultúra intézményrendszerének megújitását, illetve a krízisterületeken a társadalmi leszakadás hátterének megszüntetését célozza. Az eredeti építészeti struktúra és épületállomány megtartásával együtt járó felújítást és lakásépitést a Palotanegyed és a Népszínház negyed programja tartalmazza. Elöbbi a negyed jó és közepes állapotú palotáinak, 4-6 emeletes bérházas társasházainak megújitását tüzi zászlajára, míg utóbbi a Köztársaság tér és az Erkel színház felújitását, illetve a Népszínház utca régi karakterének megőrzését veszi tervbe. Mindkét területen városrendezési szabályozással és társasház-felújitási pályázati rendszer múködtetésével támogatja az önkormányzat a programok megvalósulását. A terveket gyakorlati tapasztalatok is segítik, hiszen a Középső-Józsefvárosban a közvetlenül a Corvin Sétány Projekt területétől északra már folytattak építészeti struktúrát megörző rehabilitációt (Egedy et al. 2005).

\section{A városrehabilitáció és a bérlakásprogramok összekapcsolása}

\section{Újpest-Városközpont}

Újpest-Városközpontban az 1990-es évek elejére kézzelfoghatóvá vált a városhanyatlás, szociális problémák ütötték fel fejüket és a társadalmi kirekesztés megjelenésének is tanúi lehettünk. Az önkormányzat a városrész felújitása mellett döntött, amely két szálon indult el: egyrészt megindult az 1990-es évek második felében a leromlott állapotú önkormányzati épület- és lakásállomány felújítása saját erőböl, másrészt elindítottak egy szociális bérlakásprogramot, amelynek keretében a 
Egedy Tamás : A városrehabilitációs stratégiák szerepe az épület-és lakásállomány megújulásában.

Tér és Társadalom 20. évf. 37-56. $p$.

lakásmobilitás növelésére magas színvonalú bérlakásokat építettek. Az újpesti kezdeményezés tehát sikeresen kapcsolta össze a magántőke bevonásával müködő városrehabilitációt a helyi bérlakásprogrammal. A területen tehát egyrészt folyt a magántőke beruházásában az új lakások építése és a meglévő épületállomány felújítása, ez kiegészült az önkormányzati tulajdonban lévő Vagyonkezelö beruházásában épülö magas színvonalú bérlakás-építési programmal, illetve folyt az önkormányzati kézben lévő épület- és lakásállomány felújítása is. Az újpesti program keretében sikeresen kapcsolták össze a magán- és a közszféra beruházásait: egyrészt a lebontott épületek helyén felszabaduló telkeket magánvállalkozásoknak értékesítették, akik magas színvonalú, egyedi tervezésủ, 2-3 szintes lakóházakat építettek, és gyakran „lakással fizettek” a telekért, másrészt az új önkormányzati lakóházakban egyes lakásokat a piacon értékesítettek, vegyes tulajdont hozva létre így az épületben. A bérlakásprogram és a városrehabilitáció együttes alkalmazásával egyfajta mobilitási lánc jöhetett létre a lakónegyedben, s a városrész úgy újulhatott meg, hogy a korábbi lakóknak nem kellett elhagyniuk a negyedet. A korábbi szociális kapcsolatok és a lakóközösség ily módon fennmaradhattak, s ez erösítette a helyi identitást és a közösség összetartó erejét. Az új lakóházakba beköltözök is zömmel a kerületböl érkeztek, a korábbinál jóval fiatalabb, kisgyermekes, stabil jövedelemmel rendelkező családok voltak. E folyamatoknak köszönhetően a városrész társadalmi és fizikai megújulása napjainkra szemmel láthatóvá vált.

\section{Köbánya-Városközpont}

A leromlott állapotú épület- és lakásállomány, valamint az egyre súlyosbodó társadalmi problémáinak megoldására Köbánya önkormányzata 1998-ban rehabilitációs akcióterületté nyilvánította a Ligettelkek három tömbjét a kerület központjában. A 10 évre tervezett, 10 milliárd forintos beruházás keretében megvalósuló rehabilitációs program lényege, hogy az eredeti kisvárosias, eklektikus és szecessziós építészeti struktúra megőrzésével, a lakóépületek felújításával, esetleges bontásával és új épületek felépítésével a városrészt építészeti és társadalmi értelemben is revitalizálják.

A kőbányai rehabilitáció, melyben egyidejüleg irányítják az önkormányzati, a befektetési és magánszféra (lakástulajdonosok) elképzeléseit, két fô iránnyal bír. Az egyik cselekvési irány az önkormányzat lakásállományának átalakítása, ami a megőrzésre alkalmas lakásállomány felújításából, illetve a bontások során felszabadult területek többcélú hasznosításából áll ${ }^{4}$. Kiemelt fontosságú eleme volt ezen önkormányzati programnak a kieső lakások pótlására, a lakásmobilitás elösegítésére és a városrész imázsának emelésére létrehozott „Százlakásos” projekt, amely az önkormányzat költségalapú bérlakásépítési programjának egyik fontos eleme. A rehabilitáció másik fö vonulata a magán, illetve a vegyes tulajdonú társasházak felújítása, rehabilitációja a magántỏke bevonásával. Ennek során az önkormányzati tulajdonú épületeket a magántöke segítségével újítják fel, vagy az üresen álló telkek értékesítésén keresztül az önkormányzat serkenti a magántőke beruházásait a lakásépítésbe. Az újpesti példához hasonlóan tehát Köbánya-Városközpontban is összekapcsolták a városrehabilitációt a helyi bérlakásprogrammal. 
Egedy Tamás : A városrehabilitációs stratégiák szerepe az épület-és lakásállomány megújulásában. Tér és Társadalom 20. évf. 37-56. $p$.

Az elmúlt években a rehabilitáció eléggé vontatottan haladt az akcióterületen. A közeljövőben a hétmilliárd forintos László Liget/László Passzázs projekt fejlesztéssel próbálnak új lenduletet adni a folyamatnak. A $30000 \mathrm{~m}^{2}$-es komplex városközpont-fejlesztési beruházással valóra válik a felújítási stratégia egyik fö célkitúzése: a városközponti funkciók kiterjesztése a rehabilitációs területre. Természetesen a rehabilitációt támogató bérlakásprogram sem áll le, hiszen egy 84 lakásos, szociális elhelyezést biztosító ház építésének előkészületei kezdődtek meg 2005-ben. Az állami és önkormányzati összefogással épülö lakóház összesen megközelítőleg egymilliárd forintba kerül.

\section{A szociális városrehabilitáció}

Több nemzetközi és hazai tanulmány is rávilágított már arra, hogy egy városrehabilitációs program sikere nem feltétlenül garantált, ha kizárólag az épített környezet felújítására koncentrálunk és háttérbe szorul a társadalmi és gazdasági környezet megújítása. A fenti tapasztalatot figyelembe véve 2005-ben Magyarországon elsőként a fövárosi önkormányzat és az érintett kerületi önkormányzatok szociális városrehabilitációs modellkísérletet indítottak három lakónegyedben. A négyéves programra, amely a kőbányai Bihari úti telepet, a józsefvárosi Magdolna negyedet, valamint a ferencvárosi Dzsumbujt érinti, 1,8 milliárd forintot különített el a fơváros, ehhez járul az önkormányzatok támogatása. A projektekben az épületés lakásállomány felújítása kiegészül egy erős szociális programmal, ami elősegíti a helyi társadalom helyzetének javítását.

\section{A Magdolna negyed}

Józsefvárosban a kerületfejlesztési stratégiában körülhatárolt 11 negyed közül a társadalmi és környezeti problémákkal legjobban terhelt városrészek a Magdolna negyed és az Orczy negyed. A Magdolna negyed területen 74 kizárólag rossz minóségü, komfort nélküli vagy alacsony komfortfokozatú, 30\%-ban egyszobás, önkormányzati bérlakásokat tartalmazó ház található, melyek felújítására eddig a kerület gyakorlatilag semmit nem fordított. Ennek köszönhetően a „Magdolna negyed" Józsefváros és talán Budapest egyik legnagyobb kiterjedésủ területe, ahol a leromlott fizikai környezet, a társadalmi-gazdasági elmaradottság jellemző, a hátrányos helyzetủ családok rendkívül magas arányban vannak jelen, s így a városrész egyre jobban leszakad a kerület többi részétôl. A Magdolna negyed szociális rehabilitációjában az életminöség és a lakáskörülmények javítása érdekében kiemelt hangsúlyt kap az épület- és lakásállomány korszerúsítése és a lakókörnyezet megújítása. A program a szolgáltatások javítása mellett emeli az oktatás, a kultúra színvonalát, és elösegíti a helyi civil szervezetek együttmúködését. Ezenkívül a kisvállalkozók és kiskereskedők támogatásával, új munkahelyek teremtésével, foglalkoztatási és képzési programok indításával gazdasági rehabilitációs elemeket is tartalmaz. A helyi társadalom aktív részvételével talán valóra válik az itt élők társadalmi leszakadásának megállítása, a szegénység és a kirekesztettség megszüntetése és egy biztonságosabb 
Egedy Tamás : A városrehabilitációs stratégiák szerepe az épület-és lakásállomány megújulásában. Tér és Társadalom 20. évf. 37-56. $p$.

lakónegyed kialakítása. 2006-ban veszik fel a kapcsolatot a programban részt vevő házak lakóival, illetve megtörténik az épület és lakásállomány müszaki gépészeti felmérése. Az elkövetkezendő három évben a program 690 millió Ft fövárosi önkormányzati és 120 millió Ft önkormányzati támogatással gazdálkodhat.

\section{A Dzsumbuj}

Az 1937-ben átadott, három épuiletből álló telep egyik legfőbb problémája, hogy gyártelepi környezetbe ékelődött, és így elszigetelődött a város többi részétől. Az egymásra nyitott, többnyire $28 \mathrm{~m}^{2}$ alapterületü, szoba-konyhás otthonokból álló Dzsumbuj egyfajta zárványtelepként képzelhetö el, amely az elörehaladott gettósodási folyamat kővetkeztében koncentrálja, tartósítja és újratermeli a nyomort, és kilátástalanná teszi az itt élö 800 lakó életét (Ambrus 1988). A szociális helyzet javítására már korábban történtek lépések: 1997-ben az önkormányzat létrehozta a telepen a Dzsumbuj Help Közösségfejlesztő Központot, s 2004-től a szociális rehabilitációt előkészítỏ Külső-Ferencvárosi Szociális Rehabilitációs Programiroda is megkezdte munkáját. A projekt sikere érdekében együttmủködésre kapnak felkérést a szociális, egészségügyi, közigazgatási, bủnmegelőzési, foglalkoztatási, kisebbségi, gyámügyi, oktatási, felnőttképzési és drogmegelőzési területeken érintett szervezetek. A rehabilitáció végsô célja lényegében az, hogy az itt élóket a szociális támogató program segítségével visszavezessék a társadalomba, és elősegítsék elköltỏzésủket a telepról. Többek között képzési, felvilágosító és egészségügyi foglalkozásokat, tanodát szerveznek számukra a családmentori szolgálaton keresztül, ezenkívül adósságkezelö programba is bevonják a lakókat. Mivel a lakások minősége nem teszi lehetővé sem a gazdaságos felújítást, sem a piaci értékesítést, az utolsó lépés a Dzsumbuj teljes kiürítése és felszámolása lesz a program végén. A program teljes bekerülési összege elérheti a 2,5-3 milliárd forintot, így a szociális rehabilitáció csak az első lépés a program végrehajtásában.

\section{A Bihari út}

A Bihari út 8/C lakótömbje a Dzsumbuj bérkaszárnya-sorához hasonlóan, a harmincas évek második felében épült. Kőbánya önkormányzata a szociális város-rehabilitáció keretében próbál jobb feltételeket biztosítani a száz darab $25 \mathrm{~m}^{2}$-es szobakonyhás szükséglakásban, nagyon rossz körülmények között élő embereknek. Az épületek külső renoválása mellett a lakáshelyzet javítását egyes lakások egybenyitásával, az életkörülményeket pedig komfortosítással oldják meg. Mindemellett természetesen a lakókörnyezet revitalizálására is figyelmet fordítanak, amit elősegít a környék Dzsumbujnál valamivel kedvezöbb közlekedési és közmü-infrastruktúrája. A lakókörnyezet javítását a telek zöldterületi fejlesztésével és sportpálya építésével próbálják megoldani, aminek kialakításába bevonják a helyi munkanélkülieket is. Mint eż is mutatja, kiemelt hangsúlyt kap a munkahelyteremtés és ezen keresztül a foglalkoztatottsági helyzet javítása. A szociális vonalat egészségügyi programmal 
Egedy Tamás : A városrehabilitációs stratégiák szerepe az épület-és lakásállomány megújulásában. Tér és Társadalom 20. évf. 37-56. $p$.

TÉT XX. évf. 2006

A városrehabilitációs stratégiák...

51

erősítik: gyermeknőgyógyászat és helyi tbc-szürés müködik majd a telepen a program végére. Emellett szociális foglalkozásokat, tanácsadást és kulturális programokat is szerveznek helyben. A projekt 476 milliós fövárosi és 208 milliós önkormányzati befektetésbỏl valósul meg.

\section{A vidéki nagyvárosok rehabilitációs stratégiái}

\section{Spontán rehabilitáció a lakosság részvételével}

\section{Györ}

Györ Sziget városrészében az 1990-es évek elejétöl folyamatosan futott fel a spontán rehabilitáció. A terület a 2001. évi népszámlálás adatai szerint Györ más városrészeihez viszonyítva a lakások kedvezötlenebb szobaszám és alapterület szerinti megoszlásával tủnik ki. Lakásállományában az 50-60 $\mathrm{m}^{2}$-es összkomfortos lakások súlya a meghatározó, de nagyobb arányban találunk egyszobás lakásokat, illetve önkormányzati lakások is nagyobb számban vannak jelen. Jelenleg a demográfiai mutatók sem kedvezőek, hiszen magas az idős korúak és az egyszemélyes háztartások aránya. A mintaterületet túlnyomórészt az alsó-középosztályt képviselö ipari foglalkozású szak- és betanított munkás és kisfoglalkoztató rétegek képviselöi lakják.

A terület régen önálló település volt, s 1905-ben csatolták a megyeszékhelyhez. A lakónegyed a korábbi rendezési tervekben - egy új lakótelep tervezett felépítése miatt - bontásra ítélt területként szerepelt, s az emiatt elrendelt és az 1980-as évek elejéig érvényben lévő bontási tilalom a városrész fejlődését gyakorlatilag lehetetlenné tette. A terület későbbi fejlődését meghatározta a termálfürdő megépítése, $s$ az építési tilalom feloldása után az évtized második felében a lakáspiac újra felfedezte a városnegyedet. A több helyen még leromlott állapotú lakóépületek ellenére a városrésznek sajátos, kellemes hangulata van, s a pozitív tendenciáknak köszönhetöen egy társadalmi felértékelődési folyamat vette kezdetét a lakónegyedben. Ez többek között annak köszönhető, hogy a rendszerváltozás után egy spontán rehabilitációs folyamat indult meg a városrészben, amelyben a fő szerepet a lakosság építési-felújítási tevékenysége és a magántársaságok (ingatlanfejlesztök, építöcégek) beruházásai játsszák. Így alapvetően különbözik a belváros 1980-as években központi irányítással és finanszírozással megvalósult rehabilitációjától. A spontán rehabilitáció keretében egyrészt tanúi lehetünk a családi és kisebb társasházak öneröböl történő felújításának, másrészt az elmúlt években több új társasház épült fel a mintaterület központi és peremi részén. A területen az elmúlt években elindult megújulásai folyamat nyomai már láthatók, azonban ez a lakásállomány és a népesség összetételében még csak korlátozottan jelentkezik (Egedy 2005). 
Egedy Tamás : A városrehabilitációs stratégiák szerepe az épület-és lakásállomány megújulásában. Tér és Társadalom 20. évf. 37-56. $p$.

\section{A belváros rekonstrukciója a bérlakásállomány megújitásával}

\section{Szeged}

Szeged belvárosában a Tisza Lajos körút-Aradi Vértanúk tere-Oskola utca-Deák Ferenc utca-Arany János utca által határolt rehabilitációs területen a tradicionális, sürủ beépítésü, eklektikus épületek többsége a 19. század utolsó harmadában és részben a 20. század elsö évtizedeiben épült fel. A terület lakásállománya és a lakónépesség a fövárosi kerületek és a vidéki nagyvárosi mintaterületek hasonló karakterü városrészeinél kedvezőbb mutatókkal rendelkezik.

A történelmi belváros nagymértékủ és látványos átépítése 1998-tól 2003-ig tartott, s kiindulópontja volt egy hosszabb távú felújítási programnak. Ennek keretében 2000-ben elkészült Szeged történeti belvárosának részletes szabályozási terve, illetve ugyanebben az évben az önkormányzat rendeletet alkotott a helyi építészeti örökség védelméröl. Ugyancsak 2000-ben kezdődött meg a Kárász utca, Klauzál tér közterületének teljes rehabilitációja, aminek köszönhetően a városrész visszakapta eredeti funkcióját és tartalmát (1. kép). A rehabilitációt segíti, hogy az önkormányzat - Ferencvároshoz és Józsefvároshoz hasonlóan - nem idegenítette el a belvárosi ingatlanokat, így a felújítási tevékenység könnyebben kivitelezhetö. Ennek során a történeti belvárosban az önkormányzati bérlakásállományt is felújítják, $\mathrm{s}$ a komfortnélküli (kényszer) kislakásokat magasabb színvonalú, az igényeknek jobban megfelelö, korszerủ, nagyobb méretű lakásokká alakítják át. Ez a folyamat természetesen a bérlőstruktúra átalakulását is magával hozza.

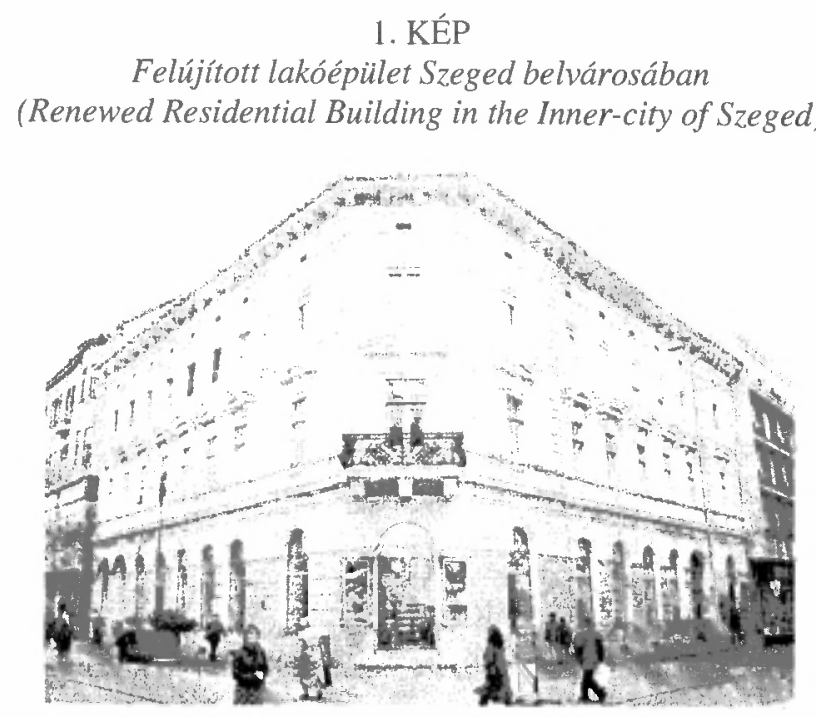

Forrás: Saját fotó.

Összességében megállapíthatjuk, hogy a szegedi belvárosi rehabilitációs terület egy viszonylag kedvezö lakásállománnyal és demográfiai mutatókkal rendelkező városrész, ahol a körülmények kedvezőek a lakónegyed továbbfejlödéséhez. Ezt a 
Egedy Tamás : A városrehabilitációs stratégiák szerepe az épület-és lakásállomány megújulásában. Tér és Társadalom 20. évf. 37-56. $p$.

TÉT XX. évf. 2006 - 1

A városrehabilitációs stratégiák ...

53

folyamatot a belváros rekonstrukciója alapvetỏen támogatja, így a közeljövőben várható a mintaterület további felértékelődése.

A belvárosok, a történelmi városmagok felújítása ma a leggyakrabban alkalmazott rehabilitációs eljárások közé tartozik. A folyamat az 1980-as években indult útjára (pl. Györ belvárosának helyreállítása), s a rendszerváltozás után kapott nagyobb lendületet (pl. Debrecen, Székesfehérvár, Miskolc, Nyíregyháza, Sopron).

\section{Régi városrészek revitalizálása, új városközpontok kialakítása}

\section{Debrecen}

A debreceni mintaterület a belvárostól mintegy $2 \mathrm{~km}$-re délre fekszik, s Epreskert lakótelep néven ismert. Tipikus, az 1970-es években felépült lakótelepi lakásállomány található a területen, összkomfortos, döntöen kétszobás, 50-60 m²-es lakásokkal. A lakásállomány jelentős része önkormányzatj kézben van, illetve szolgálati lakásként funkcionál. A népesség összetételében is részben a lakótelepi karakter érvényesül: jellemző a kisgyerekes családok magas és az időskorúak átlagosnál lényegesen alacsonyabb aránya. A népességen belül meghatározó az általános és középiskolai végzettségüek aránya, a foglalkoztatottak döntően a szolgáltatási szektorban dolgoznak szakképzett, beosztott szakalkalmazottként, egyúttal kevés a közép- és felsővezetö.

A közelmúltban lezajlott lakótelep-rehabilitációnak köszönhetően a lakásállomány helyzete javult, s ezzel párhuzamosan a terület korábbi lakónépessége kicserélődött. A terület fejlesztése egyébként megelőzte a belváros rehabilitációs programjának kidolgozását, ilyen szempontból az önkormányzat első jelentősebb felújítási próbálkozásaként is értékelhetö ${ }^{5}$. A lakótelep mellett magánberuházás keretében az elmúlt 5 évben felépült egy több épulietböl álló társasházi tömb, ami gyakorlatilag egybeépült a lakóteleppel, de töle építészeti megjelenésében, a lakások minőségében és lakáspiaci helyzetében is alapvetően különbözik. A tömb megépülése volt az első jele a terület kezdődő felértékelödésének, s a szomszédos lakóteleprehabilitációval együtt meghatározó szerepet játszhat a lakónegyed további fejlödésében, illetve egy új városközpont kialakulásában.

\section{Pécs}

Pécs városrehabilitációs stratégiájában a belváros felújitása prioritást élvez, azonban a területi egyensúly biztosítása érdekében az önkormányzat támogatja a keleti városrészekben - köztük példaterületünkön, a Budai városban - megvalósuló beruházásokat is. Ezek között csomópont-átalakítások, a kereskedelmi funkció megerösítése és természetesen a lakás- és épületállomány megújítása szerepelnek (2. kép). Nem titkolt cél, hogy a terület turisztikai pozícióját erösítsék, bevezetve ezáltal a keleti irányból érkező turistaforgalmat a belvárosba, egyúttal tovább bỏvítve a város vonzerejét.

A Budai város hagyományos beépítésü lakónegyed, ahol egyaránt megtalálható a szoros beépítettség mellett a kertes, családi házas építkezés, illetve a belvároshoz 
Egedy Tamás : A városrehabilitációs stratégiák szerepe az épület-és lakásállomány megújulásában. Tér és Társadalom 20. évf. 37-56. $p$.

54 Egedy Tamás

TÉT XX. évf. 2006

közelebb fekvő részen többszintes társasházakkal, valamint lakótelepi épületekkel is találkozhatunk. A terület lakásállományában az 50-60 m²-es, kétszobás, összkomfortos lakások képezik a meghatározó szegmenset, az önkormányzati bérlakások kis szereppel bírnak. A demográfiai összetételre jellemzö, hogy nagyon sok, csak öregkorúból álló háztartás fordul elö a területen, és magas az inaktívak aránya, illetve elsösorban az alsó-középosztályhoz tartozó rétegek képviseltetik magukat. A mintaterület lakáspiaci fejlödése kedvezőtlen helyzetböl indult, de a felújítási tevékenységnek köszönhetöen, különösen az 1990-es évek második felében megindult a tehetősebb rétegek beáramlása a területre, megnőtt a beköltözések száma, és fellendült a lakásmobilitás.

2. KÉP

A pécsi Budai város revitalizálása a lakókörnyezet felújitásával és új funkciók kialakitásával (Revitalisation of the Residential Area in „Budai város” Pécs)

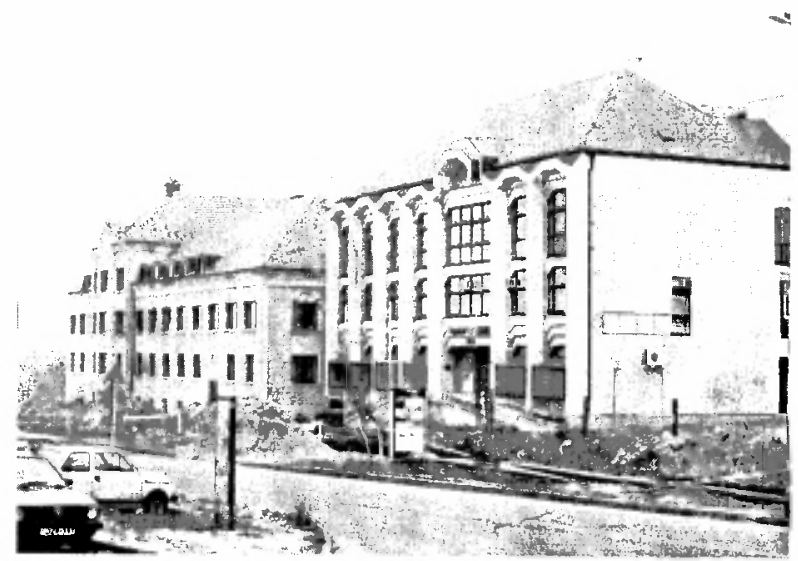

Forrás: Saját fotó.

\section{Összefoglalás}

Tanulmányunkban áttekintettük azokat az állami és önkormányzati stratégiákat, illetve fővárosi és vidéki nagyvárosi példákat, amelyek az épület- és lakásállomány megújulásában fontos szerepet játszhatnak.

Mint az a Nemzeti Fejlesztési Tervekből kiderült, a városrehabilitációt kormányzati szinten egyértelmủen a fizikai (épített) környezet felújításával azonosítják, a lakónegyedek szociális és gazdasági rehabilitációja még nem épült be szervesen a politikai köztudatba. A szociális és gazdasági rehabilitáció egyes elemei más prioritásokba és operatív programokba integráltan ugyanakkor felfedezhetök mindkét fejlesztési tervben.

$\mathrm{Az}$ állami szintủ stratégiák kidolgozásában és megvalósításában a politika meghatározó szerepet játszik. Szakmai téren ennek inkább negatív hatásaival szembesülhetünk, hiszen sok, szakmailag alátámasztott és jól kidolgozott elképzelés válik a 
Egedy Tamás : A városrehabilitációs stratégiák szerepe az épület-és lakásállomány megújulásában.

Tér és Társadalom 20. évf. 37-56. $p$.

TÉT XX. évf. 2006 - 1

A városrehabilitációs stratégiák ...

55

rövidtávú politikai akciók áldozatává. Emellett a politikai ciklusokban történő gondolkodásmód is hátráltatja a hosszútávú, átfogó stratégiák kidolgozását és alkalmazását.

A rendszerváltozás utáni években az épület- és lakásállomány megújítása egy-két sikeres rehabilitációs programtól eltekintve háttérbe került. Az 1990-es évek második felében ismerte fel a kormányzat, hogy a lakások állapotának leromlásából és a lakásépítések számának drasztikus visszaeséséből eredő problémákat kezelni kell, illetve a lakótelepek és a városi lakókörnyezet megmentése érdekében állami szintủ beavatkozásokra van szükség. 2000 után jelentek meg az első programok, és a lakáshelyzet javítása egyre inkább a politikai párbeszéd és az állami szintủ beavatkozások homlokterébe került. Örvendetes tény, hogy az elmúlt 10 évben az épített környezet felújítására fordítható állami hozzájárulások összege évröl évre emelkedik. Problematikus ugyanakkor, hogy a rehabilitáció témakörébe sorolható intézkedések még nem állnak össze egységes stratégiává és az épített kömyezet megújításához képest a társadalmi és gazdasági megújító programok lépéshátrányban vannak állami szinten. Az állami programok másik sarkalatos kérdése a finanszírozás, ugyanis az EU utófinanszírozásos rendszere, illetve a hazai programokhoz szükséges sajáterő elöteremtése mindmáig megnehezíti az önkormányzatok, a társasházak és a lakosság részvételét a pályázatokban és a projektek végrehajtásában. Az erre a célra kidolgozott hitelprogramok ugyanakkor ennek a problémának csak átmeneti megoldását jelenthetik, a rendszer finanszírozását új alapokra kell helyezni, s nagyobb szerepet kell biztosítani a magántőke részvételének és a PPP típusú modellnek.

A fövárosi és vidéki nagyvárosi rehabilitációs példák rávilágítottak arra, hogy a lakónegyedek a városon belüli elhelyezkedésük, népességszámuk, a tulajdonviszonyok, a lakásállomány minősége és a társadalmi kirekesztés stb. szempontjából rendkívül összetettek és sokfélék lehetnek, ennek ellenére az alapvető problémák mégis általában mindenhol hasonlók és jól körvonalazhatók. A felvázolt különbözö stratégiák, próbálkozások egyúttal arra engednek következtetni, hogy az eddigi hagyományos hozzáállással és eszköztárral a lakónegyedekben megjelenő problémák kezelése kevésbé hatékony és sikeres, így az intézményeknek és a lakónegyedeknek új eljárásokat és munkamódszereket kell megismerniük és alkalmazniuk a rehabilitáció során. Ekkor többek között mérlegelniük kell, hogy a tulajdonviszonyok (önkormányzati és magántulajdon aránya) milyen léptékü projekteket tesznek lehetővé (mikro- vagy megaprojekt), dönteni kell a finanszírozásról (önkormányzati tỏke indukáló hatása, különbözö források akkumulálása, magántőke bevonása), ki kell dolgozni a rehabilitációs stratégiát világos és érthetỏ célokkal, meg kell határozni az új építés és a bontás arányait, illetve létre kell hozni az együttmúködést a felújitásban részt vevő szereplők között és össze kell hangolni a különböző érdekeket.

A bemutatott példák alapján azt is elmondhatjuk, hogy a fizikai rehabilitáció, a városszerkezeti és építészeti megoldások jelentöségét még mindig túlbecsülik a szakemberek és túlzóak a velük kapcsolatos várakozások. Egyelöre még csak kísérleti stádiumban vannak az épített, társadalmi és gazdasági környezet együttes rehabilitációját célzó programok. Pedig csak az ilyen integrált, az ágazatok közötti kölcsönös együttmüködésen alapuló, körültekintő tervezést és kivitelezést igénylö 
Egedy Tamás : A városrehabilitációs stratégiák szerepe az épület-és lakásállomány megújulásában.

Tér és Társadalom 20. évf. 37-56. $p$.

projektek lehetnek sikeresek. Természetesen emellett nem feledkezhetünk meg a lakónegyedben rejtőző humán és anyagi erőforrások kiaknázásáról, a nonprofit 'harmadik szektor' bevonásáról, illetve a helyi lakosság aktivizálásáról sem.

\section{Jegyzetek}

1 A Panel Plusz lehetőséget nyújt arra is, hogy a lakóközösségek, önkormányzatok akár önálló hitelt is igényeljenek a Panel Plusz keretéböl, amennyiben nem élnek az említett egyharmados állami támogatással. Ebben az esetben a felújítási költségek $25 \%$-át kell saját eröként felmutatni.

2 A 2000. évi intézkedésnek köszönhetỏen az állami támogatású lakáshitelek gyors térnyerésével a lakosság eladósodási folyamata 200I-ben jelentösen felgyorsult. A támogatott hitelek nagyarányú feelvétele miatt a kormányzat 2004-ben a forint alapú hitelek felvételének feltételeit jelentösen szigorította, ami az állami támogatású hitelek felvételének drámai visszaesését és a deviza alapú hitelek felvételének felfutását hozta magával.

3 Az alacsony minöségú lakások arányának folyamatos csökkentésével a jelenlegi 7500 lakásos portfoliót 4000-4 500 lakásra tervezik lecsökkenteni.

A Ligettelkek rehabilitációjának megkezdése óta már több ingatlant teljesen vagy részben lebontottak, ipari telephelyet megszüntettek. Eddig öt épületet önkormányzati és fövárosi forrásokból hozták rend5 be, illetve az önkormányzat külső vállalkozó bevonásával 250 lakás épútését kezdeményezte.

Az átfogó rehabilitációs program az 1994-ben alakított Cívisház Rt. irányításával 2000-ben indult tanulmánytervek készítésével, majd a konkrét lépések 2001-ben indultak. A felújitás középpontjában a Kiskörút mentén kisajátítással kialakított tömbök és a lakásállomány rehabilitációja áll, melynek zászlóshajó projektjei a Gambrinus köz rehabilitációja, a Széchenyi u. 32-34. és az Arany J. u. 37. alattj lakó- és irodaház felépítése, valamint a Révész téren az ưj igazságügyi szolgáltató központ kialakítása.

\section{Irodalom}

Ambrus P. (1988) A Dzsumbuj. Budapest, Magvető Kiadó.

Egedy T. (2005) A városrehabilitáció hatásai a lakásmobilitásra és a társadalmi mozgásfolyamatokra Egedy T. (szerk.) Városrehabilitáció és társadalom. Budapest, MTA FKI. 103-158. o.

Egedy T.-Kovács Z.- Székely G.-Szemző H. (2005) Fövárosi rehabilitációs programok és eredmények. - Egedy T. (szerk.) Városrehabilitáció és társadalom. Budapest, MTA FKI. 175-188. o.

Locsmándi G. (2005) Városmegújítás a Ferencvárosban. - Egedy T. (szerk.) Városrehabilitáció és társadalom. Budapest, MTA FKI. 201-227. o.

Parkinson, M. (1996) Strategic approaches for the area regeneration: a review and a research agenda. Paper prepared for the Area Regeneration Programme for the Joseph Rountree Foundation

Roberts, P.-Sykes, H. (2000) Urban Regeneration. - A Handbook. SAGE Publications, London. 320 o.

\section{URBAN REGENERATION STRATEGIES IN THE RENEWAL OF THE BUILDING- AND DWELLING STOCKS IN HUNGARY}

\section{TAMÁS EGEDY}

In the decade after the transformation decision makers on state, regional and local levels gradually recognized the importance of the renewal of run-down building and dwelling stocks. It took some time to manage and finance the rehabilitation process with the envolvement of adequate strategies. During the last decade first succesful regeneration strategies turned up both on state and local levels. The present paper outlines the main results of these rehabilitation efforts and highlights the role of rehabilitation strategies of the state, the national capital and the major cities to renew the building and dwelling stocks. 